\title{
Thermodynamic Evaluation of PTC based Organic Rankine Cycle for Power \& Cooling
}

\author{
Devendra Kumar Gupta, Rajesh Kumar and Naveen Kumar
}

\begin{abstract}
The paper focuses on thermodynamic evaluation (first and second law) for PTC based organic Rankine cycle with single ejector (EORC) and organic Rankine cycle with double ejector (DEORC) using refrigerant R141b as working fluid and Therminol VP1 as heat transfer fluid. Thermal energy storage tanks are used to store the PTC heat, which provides the continuous net power output and cooling during insufficient solar radiation. The thermodynamic evaluation is carried out to evaluate the performance of PTC field based EORC \& DEORC system which produces power and cooling simultaneously. Parametric analyses of EORC and DEORC show that inlet temperature and pressure of turbine at various extraction ratio has the significant effect on first \& second law efficiency and cooling to power ratio of this system. It is also found that, annual average energy output of EORC and DEORC is 4710.57 MWh and 5104.97 MWh respectively while annual average exergy output of EORC and DEORC is 3893.86 MWh and 3436.27 MWh respectively.
\end{abstract}

Keywords-Solar energy; PTC Field; Ejector; First Law Efficiency; Second Law Efficiency: Entrainment Ratio; EORC; DEORC; Cooling/Power Ratio.

\section{INTRODUCTION}

As the depletion of conventional energy sources is going on and due to the use of fossil fuel for producing the power cause the emissions of green-house gases like $\mathrm{CO}_{2}, \mathrm{CO}$, NOx etc. which results in global warming. The conventional methods for the production of refrigeration use chlorofluorocarbons (CFCs) and hydro-fluorocarbon (HCFC) refrigerants which causes Ozone depletion and consequently green-house effect.

The renewable energy i.e. solar thermal can be used instead of fossil fuels to reduce the $\mathrm{CO}_{2}$ emissions. Concentrated solar power (CSP) technologies (solar power tower, paraboloid dish, parabolic trough collector and linear Fresnel reflectors) are used to produce the thermal energy of high temperature and transfer it to the heat transfer fluid [1]. Concentrated solar power plants are gaining increasing interest, by using the parabolic trough collector system due to their advantages in terms of light weight in construction, lower operating cost and higher efficiency. Parabolic trough collector (PTC) technology is the best technology among all CSP technologies for power generation. Reference [2] discussed on exergy analysis and parametric study of PTC on different mass flow rates and concentration ratios for power generation. Their result shows that the exergy output,

Published on January 24, 2017.

D.K. Gupta, R. Kumar and N. Kumar are with Department of Mechanical Engineering, Delhi Technological University (Government of NCT of Delhi), Bawana Road, Delhi-110042, India.

(e-mail: d.k.gupta6873@gmail.com, dr.rajeshmits@gmail.com, naveenkumardce@gmail.com ) exergetic and thermal efficiencies are enhanced as the solar intensity increases. Reference [3] presented an exergy analysis of parabolic trough solar receiver. Their result shows that inlet temperature of heat transfer fluid and solar irradiance has significant effect on the thermal and exergetic performance of the PTC. As inlet temperature of heat transfer fluid increases the exergy efficiency increases but energy efficiency decreases.

Due to the variation in day-night solar irradiation, it is not possible to run the power plant continuously using CSP technology alone. The working of CSP can be enhanced by the incorporation of thermal energy storage (TES) system. Solar thermal energy can be stored during the peak sunshine hours and utilized in non-availability of sunshine hours as well as night cycle for the production of power. Reference [4] demonstrate the feasibility of two tank molten salt storage for parabolic trough solar plants. Their findings show that the use of thermal storage systems improve continuous operation of solar thermal plant and reduces the specific electricity cost. Reference [5] designed a solar thermal power plant with thermal storage for $1 \mathrm{MWe}$ capacity at DNI of $0.6 \mathrm{~kW} / \mathrm{m}^{2}$. The plant produces about 0.8 MWh of energy output at a capacity factor of $15.6 \%$. Reference [6] analyzed an organic Rankine cycle coupled with PTC using thermal storage has been optimized financially and energetically. Their findings show that the most suitable working fluid is cyclohexane for producing 1 MWe with PTC field.

In order to explore the solar thermal technology efficiently, the combined power and ejector cooling cycle had been proposed by many researchers. Reference [7] developed a computer programme and studied the effect of variation of performance parameters on combined power and cooling cycle. It is shown that ejector refrigeration system is more economical than absorption refrigeration system. A combined power and ejector cooling cycle was proposed by Reference [8] using R245fa as the working fluid. Their results shown that as generator temperature increases from $335 \mathrm{~K}$ to $415 \mathrm{~K}$, energy efficiency increase from $15.8 \%$ to $38.0 \%$ and exergy efficiency increase from $45.2 \%$ to $57.2 \%$ respectively. The generating temperature cannot be increased beyond a limit due to increase in turbine size. Reference [9] developed a computer program for a combined power and ejector cooling cycle using R123 as the working fluid to determine the effects of various operating parameters on the performance of the cycle. Their results show that the first and second law efficiency increase with the increase in evaporator temperature, and maximum exergy losses occurs in the boiler and ejectors. In addition to this, there is increase in first law efficiency and decrease in second law efficiency with increase in turbine inlet pressure. Reference [10] investigated the performance of a combined 
power and ejector refrigeration cycle from thermodynamic point of view and determine the optimum values of the turbine and pump inlet pressures which minimize the total thermal conductance of the cycle for the working fluid considered. Reference [11] analyses a combined power and ejector cooling system using low grade energy as heat source. The system performance were compared for five working fluid ( HFE7100, HFE7000, methanol, ethanol, water) at a source temperature of $120^{\circ} \mathrm{C}$, evaporator temperature of $10^{\circ} \mathrm{C}$ and condenser temperature of $35^{\circ} \mathrm{C}$. Methanol shown the highest efficiency $(19.50 \%)$ followed by ethanol and water $(17.30 \%)$. Their results also shown that the heat source temperature, condenser temperature and evaporator temperature have significant effect on the power output, ejector entrainment ratio and thermal efficiency of the system. An energy and exergy analyses of combined power and ejector refrigeration cycles was reported by [12][15] which shows that the maximum irreversibility/exergy loss occurs in heat addition process followed by the ejector and turbine.

In order to utilize the advantages of solar energy, to reduce fossil fuel consumption and alleviating environmental problems, a PTC field based EORC and DEORC is proposed for improving overall energy conversion efficiency. In EORC cooling is produce at single temperature while in DEORC cooling is produce at two different temperatures. The cycle has been analyses from both First and Second law view points and the effect of operating parameters on the performance is observed. The refrigerant $\mathrm{R} 141 \mathrm{~b}$ is used as working fluid and Therminol VP1 as heat transfer fluid. Thermal storage tanks are also used to store the thermal energy from the Sun which provides the continuous net power output during insufficient solar radiation.

\section{SYSTEM DESCRIPTION}

Fig. 1a and Fig. 1b illustrates a PTC field based EORC and DEORC respectively. Fig. 2a and Fig. $2 \mathrm{~b}$ illustrates the $\mathrm{T}$-s diagram of EORC and DEORC respectively.

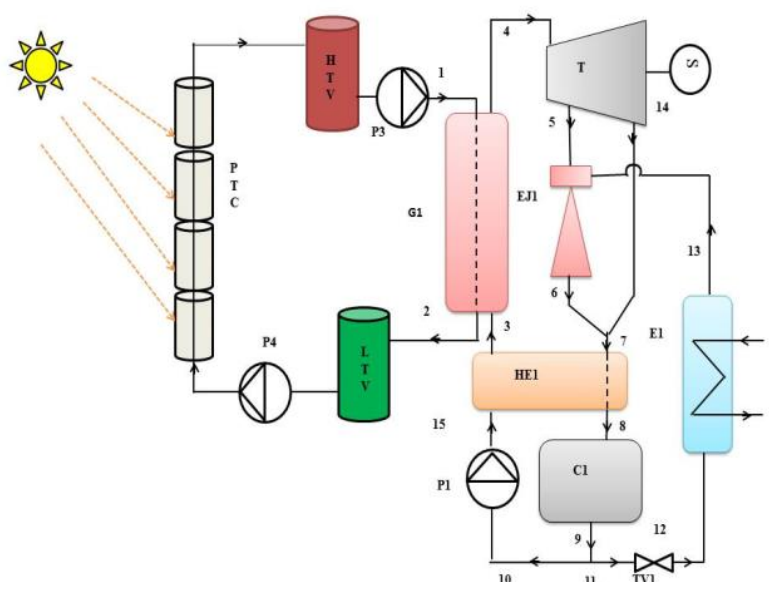

Fig. 1a Schematic diagram of Organic Rankine cycle with single ejector (EORC)

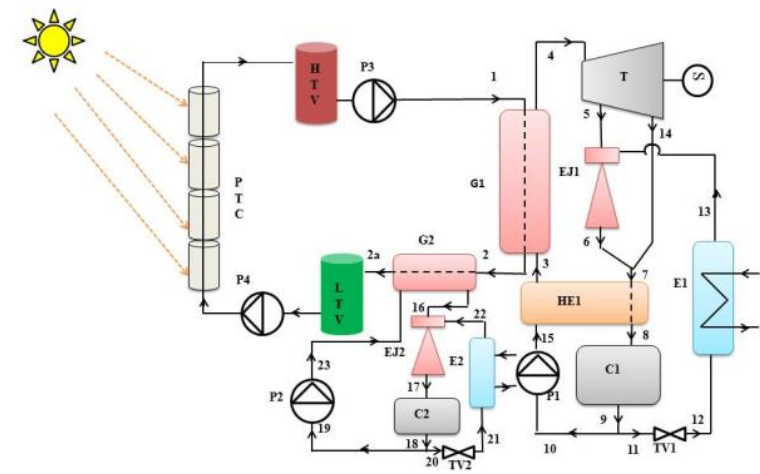

Fig. 1b Schematic diagram of Organic Rankine cycle with double ejector (DEORC)

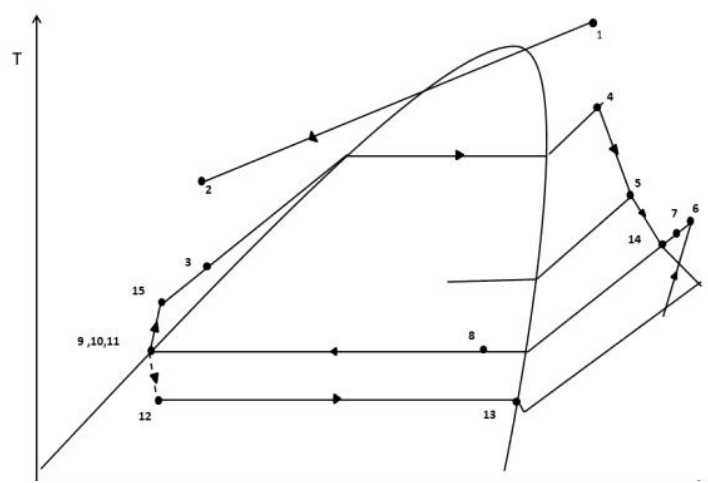

Fig. 2a T-s diagram of Organic Rankine cycle with single ejector (EORC)

The DEORC consists of parabolic trough collector (PTC) solar field, high temperature vessel, low temperature vessel, pumps, heat recovery vapor generator, turbine, ejector, condenser, throttle valve, evaporator and heat exchanger. Solar energy is used to heat the heat transfer fluid Therminol VP1 (1) with the help of PTC field. Heat transfer fluid (HTF) enters the heat recovery vapor generator $\left(G_{1}\right)$ which is used to superheat the high pressure refrigerant and leaves at (2), which again enters into the heat recovery vapor generator $\left(\mathrm{G}_{2}\right)$ to vaporize the refrigerant and return back to the PTC solar field. Superheated refrigerant vapor (4) expands in the turbine. After expansion up to the extraction pressure, refrigerant vapors are extracted (5) from turbine at extraction pressure and then it flows into the ejector nozzle, entrains secondary vapor (13) from the evaporator $\left(E_{1}\right)$ and mixes in mixing chamber of the ejector $\left(E_{1}\right)$. The ejector exit stream (6) mixes with the turbine exhaust (14) and is cooled (7-8) in the heat exchanger (HE) by rejecting heat to the refrigerant leaving from the pump $\left(\mathrm{P}_{1}\right)$ which is preheated (15-3). The refrigerant leaving from heat exchanger (8) is condensed in the condenser (C1) and converts into saturated liquid (9). The saturated liquid (9) from condenser is divided into two parts. One part (11) enters into throttle valve $\left(\mathrm{TV}_{1}\right)$ and other part (10) into pump $\left(\mathrm{P}_{1}\right)$. The saturated liquid (10) pumped with the help of pump $\left(\mathrm{P}_{1}\right)$ into the heat exchanger $(15)$. The preheated refrigerant (3) leaving from heat exchanger enters into heat recovery vapor generator $\left(\mathrm{G}_{1}\right)$ in which heat is absorbed and convert into superheated vapor (4). The saturated liquid (11) expands in the throttle valve $\left(\mathrm{TV}_{1}\right)$ to the evaporator pressure (12). The refrigerant (12) enters into the evaporator 
$\left(E_{1}\right)$ and produce the cooling effect by evaporation of refrigerant (12-13). The refrigerant vapour (16) flows into the ejector nozzle and entrains secondary vapor (22) from the evaporator $\left(E_{2}\right)$ mixes in mixing chamber of the ejector. The ejector $\left(\mathrm{EJ}_{2}\right)$ exit stream (17) is condensed in the condenser $\left(\mathrm{C}_{2}\right)$ and converts into saturated liquid (18). Saturated liquid (18) is divided into two parts. One part (20) enters into throttle valve $\left(\mathrm{TV}_{2}\right)$ and other part (19) into pump $\left(\mathrm{P}_{2}\right)$. The saturated liquid (19) pumped with the help of pump $\left(\mathrm{P}_{2}\right)$ into the heat recovery vapor generator $\left(\mathrm{G}_{2}\right)$ and converts into saturated vapor (16). The saturated liquid (20) expands in the throttle valve $\left(\mathrm{TV}_{2}\right)$ to the evaporator pressure (21). The refrigerant (21) enters into the evaporator $\left(E_{2}\right)$ and produce the cooling effect by evaporation of refrigerant (21-22). The system description of organic Rankine cycle with single ejector (EORC) is same as DEORC.

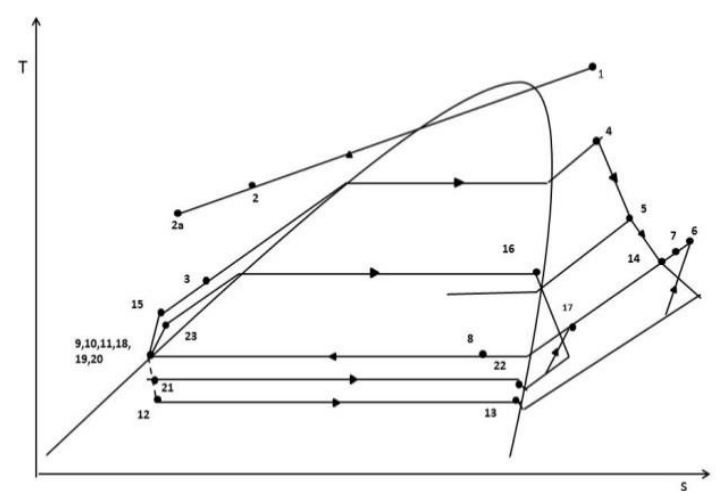

Fig. 2b T-s diagram of Organic Rankine cycle with double ejector (DEORC)

For the thermodynamic analysis, the parameters considered for the operation of EORC and DEORC are depicted in "Table I".

TABLE I: MAIN PARAMETERS CONSIDERED FOR THE ANALYSIS

\begin{tabular}{ll}
\hline Atmospheric Temperature $\left({ }^{\circ} \mathrm{C}\right)$ & 25 \\
Atmospheric pressure $(\mathrm{MPa})$ & 0.10135 \\
Turbine inlet Temperature $\left({ }^{\circ} \mathrm{C}\right)$ & 150 \\
Turbine inlet pressure $(\mathrm{MPa})$ & 0.6 \\
Turbine extraction pressure $(\mathrm{MPa})$ & 0.24 \\
Extraction ratio & 0.3 \\
Turbine isentropic efficiency $(\%)$ & 85 \\
Pump isentropic efficiency $(\%)$ & 70 \\
Condenser temperature $\left({ }^{\circ} \mathrm{C}\right)$ & 30 \\
Evaporator $\left(\mathrm{E}_{1}\right)$ temperature $\left({ }^{\circ} \mathrm{C}\right)$ & -5 \\
Evaporator $\left(\mathrm{E}_{2}\right)$ temperature $\left({ }^{0} \mathrm{C}\right)$ & 0 \\
Effectiveness of the heat exchanger & 0.75 \\
Aperture area $\left(\mathrm{m}^{2}\right)$ & 10000 \\
Direct normal irradiance $\left(\mathrm{kWm}{ }^{-2}\right)$ & 0.60 \\
HTF temperature inlet to $\mathrm{HRVG}\left({ }^{\circ} \mathrm{C}\right)$ & 160 \\
HTF temperature exit to $\mathrm{HRVG}\left({ }^{\circ} \mathrm{C}\right)$ & 90 \\
HRVG efficiency $(\%)$ & 100 \\
Nozzle efficiency $(\%)$ & 90 \\
Mixing chamber efficiency $(\%)$ & 85 \\
Diffuser efficiency $(\%)$ & 85 \\
\hline
\end{tabular}

\section{THERMODYNAMIC ANALYSIS}

Based on mass, momentum and energy equations the entrainment ratio is developed by [13].

$$
\mu=\sqrt{\eta_{\mathrm{n}} \eta_{\mathrm{m}} \eta_{\mathrm{d}}\left(\mathrm{h}_{\mathrm{pf}, \mathrm{n} 1}-\mathrm{h}_{\mathrm{pf}, 2 \mathrm{~s}}\right) /\left(\mathrm{h}_{\mathrm{mf}, \mathrm{ds}}-\mathrm{h}_{\mathrm{mf}, \mathrm{m}}\right)}-1
$$

The enthalpy and entropy values for R141b at salient state points of the EORC and DEORC are taken from NIST Standard Reference Database 23, REFPROP 6.01(1998) [16].

\section{A. First law analysis for DEORC}

Solar energy received from the Sun

$$
\dot{\mathrm{Q}}_{\text {Solar }}=\mathrm{IA}_{p}
$$

where $\mathrm{I}=$ Direct normal irradiance $\left(\mathrm{kWm}^{-2}\right), \mathrm{A}_{\mathrm{p}}=$ Aperture Area $\left(\mathrm{m}^{2}\right)$

Heat gain in the PTC field for DEORC

$$
\begin{aligned}
\dot{\mathrm{Q}}_{\text {gain }}=\dot{\mathrm{m}}\left(\mathrm{h}_{1}-\right. & \left.\mathrm{h}_{2 \mathrm{a}}\right)=\eta_{\mathrm{I}, \text { PTC }} \mathrm{IA} \mathrm{A}_{p} \\
& =\mathrm{m}_{4}\left(\mathrm{~h}_{4}-\mathrm{h}_{3}\right)+\mathrm{m}_{16}\left(\mathrm{~h}_{16}-\mathrm{h}_{23}\right)
\end{aligned}
$$

where $_{\mathrm{I}}$, PTC $=$ First law efficiency of PTC field

$$
\eta_{I,} \text { PTC }=a-b\left[\frac{T_{m}-T_{0}}{I}\right]-c\left[\frac{\left(T_{m}-T_{0}\right)^{2}}{I}\right]
$$

$\mathrm{a}=$ optical efficiency $=0.7, \mathrm{~b}=$ first order loss coefficient $=0.1, \mathrm{c}=$ second order loss coefficient $=0, \mathrm{~T}_{\mathrm{m}}=$ mean temperature $=\left(\mathrm{T}_{1}+\mathrm{T}_{2 \mathrm{a}}\right) / 2$.

The first law efficiency $\left(\eta_{I}\right)$ of the DEORC can be defined as the ratio of the net power output $\left(\dot{\mathrm{W}}_{\text {net }}\right)$ and cooling output in both the evaporators $\left(\dot{\mathrm{Q}}_{\mathrm{e}_{1}} \& \dot{\mathrm{Q}}_{\mathrm{e}_{2}}\right)$ to the solar energy input $\left(\dot{\mathrm{Q}}_{\text {Solar }}\right)$.

$\eta_{\mathrm{I}}=$ Energy output/Solar energy input

$$
=\left(\dot{\mathrm{W}}_{\text {net }}+\dot{\mathrm{Q}}_{\mathrm{e}_{1}}+\dot{\mathrm{Q}}_{\mathrm{e}_{2}}\right) / \dot{\mathrm{Q}}_{\text {Solar }}
$$

Turbine work:

$\dot{\mathrm{W}}_{\mathrm{T}}=\dot{\mathrm{m}}_{4}\left(\mathrm{~h}_{4}-\mathrm{h}_{5}\right)+\dot{\mathrm{m}}_{4}\left(1-\mathrm{E}_{\mathrm{r}}\right)\left(\mathrm{h}_{5}-\mathrm{h}_{14}\right)$

where extraction ratio: $\mathrm{E}_{\mathrm{r}}=\dot{\mathrm{m}}_{5} / \dot{\mathrm{m}}_{4}$

Pump work: $\dot{\mathrm{W}}_{\mathrm{P}}=\dot{\mathrm{m}}_{4}\left(\mathrm{~h}_{15}-\mathrm{h}_{10}\right)$

(8)

Net power output: $\dot{\mathrm{W}}_{\text {net }}=\dot{\mathrm{W}}_{\mathrm{T}}-\dot{\mathrm{W}}_{\mathrm{P}}$

Cooling output in evaporator $\left(E_{1}\right)$

$$
\dot{\mathrm{Q}}_{\mathrm{e}_{1}}=\dot{\mathrm{m}}_{5} \mathrm{\mu}_{1}\left(\mathrm{~h}_{13}-\mathrm{h}_{12}\right)
$$

Cooling output in evaporator $\left(\mathrm{E}_{2}\right)$

$$
\dot{\mathrm{Q}}_{\mathrm{e}_{2}}=\dot{\mathrm{m}}_{16} \mathrm{\mu}_{2}\left(\mathrm{~h}_{22}-\mathrm{h}_{21}\right)
$$

Entrainment ratio:

Ejector $\left(E J_{1}\right)-\mu_{1}=\dot{\mathrm{m}}_{13} / \dot{\mathrm{m}}_{5}$

Ejector $\left(\mathrm{EJ}_{2}\right)-\mu_{2}=\dot{\mathrm{m}}_{22} / \dot{\mathrm{m}}_{16}$

\section{B. Second law analysis for DEORC}

Exergy analysis is based on second law approach. Exergy may be defined as the maximum possible reversible work obtainable in bringing the state of the system to the dead state, Mathematically 


$$
\dot{\mathrm{E}}=\dot{\mathrm{m}}\left[\left(\mathrm{h}-\mathrm{h}_{0}\right)-\mathrm{T}_{0}\left(\mathrm{~s}-\mathrm{s}_{0}\right)\right]
$$

Second law efficiency of PTC field may be reported as

$\eta_{\text {II, PTC }}=\left\{\dot{\mathrm{m}}\left(\mathrm{h}_{1}-\mathrm{h}_{2 \mathrm{a}}\right)-\mathrm{T}_{0}\left(\mathrm{~s}_{1}-\mathrm{s}_{2 \mathrm{a}}\right)\right\} / \mathrm{IA}_{\mathrm{p}} \psi$

Maximum useful work obtainable from sun radiation $(\psi)$ is calculated from [17] formula that is given as

$\psi=1-\frac{4}{3} \frac{\mathrm{T}_{0}}{\mathrm{~T}_{\text {solar }}}+\frac{1}{3}\left(\frac{\mathrm{T}_{0}}{\mathrm{~T}_{\text {solar }}}\right)^{4}$

The second law efficiency $\left(\eta_{\text {II }}\right)$ of DEORC may be reported as

$\eta_{\text {II }}=$ Exergy output/Exergy input

$$
=\left(\dot{\mathrm{W}}_{\text {net }}+\dot{\mathrm{E}}_{\mathrm{e}_{1}}+\dot{\mathrm{E}}_{\mathrm{e}_{2}}\right) / \dot{\mathrm{E}}_{\text {Solar }}
$$

where, $\dot{\mathrm{E}}_{\text {Solar }}$ is exergy input associate with solar radiation falling on PTC field, $\dot{\mathrm{E}}_{\mathrm{e}_{1}}$ is the exergy associate with cooling output in the evaporator $\left(\mathrm{E}_{1}\right)$ and $\dot{\mathrm{E}}_{\mathrm{e}_{2}}$ is the exergy associate with cooling output in the evaporator $\left(E_{2}\right)$,

$$
\begin{aligned}
& \dot{\mathrm{E}}_{\mathrm{e}_{1}}=\dot{\mathrm{m}}_{13}\left[\left(\mathrm{~h}_{12}-\mathrm{h}_{13}\right)-\mathrm{T}_{0}\left(\mathrm{~s}_{12}-\mathrm{s}_{13}\right)\right] \\
& \dot{\mathrm{E}}_{\mathrm{e}_{2}}=\dot{\mathrm{m}}_{22}\left[\left(\mathrm{~h}_{21}-\mathrm{h}_{22}\right)-\mathrm{T}_{0}\left(\mathrm{~s}_{21}-\mathrm{s}_{22}\right)\right] \\
& \dot{\mathrm{E}}_{\text {Solar }}=\mathrm{IA}_{\mathrm{p}} \psi
\end{aligned}
$$

whereT $_{\text {Solar }}$ is the Apparent Sun Temperature $=4500 \mathrm{~K}$

\section{Results AND Discussion}

The first and second law analyses is conducted for EORC and DEORC, their results are compared by varying operating parameters such as turbine inlet temperature (TIT) and turbine inlet pressure (TIP) at different extraction ratio on the performance of the cycle.

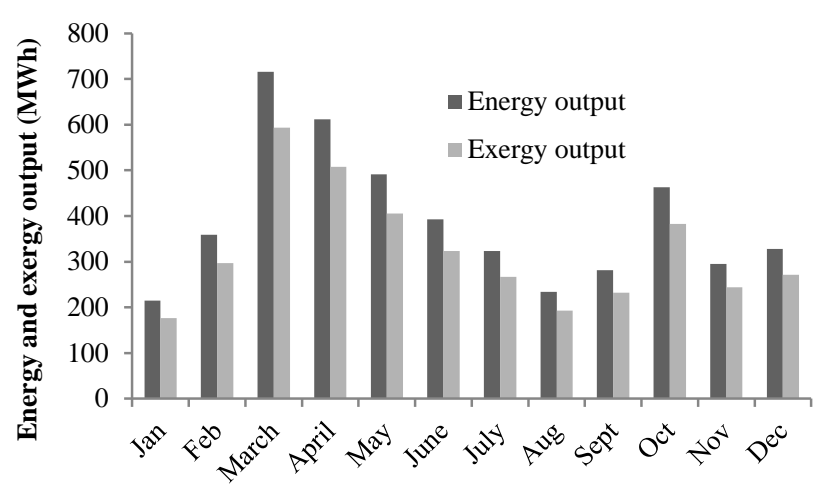

Fig. 3 Monthly energy and exergy output of EORC

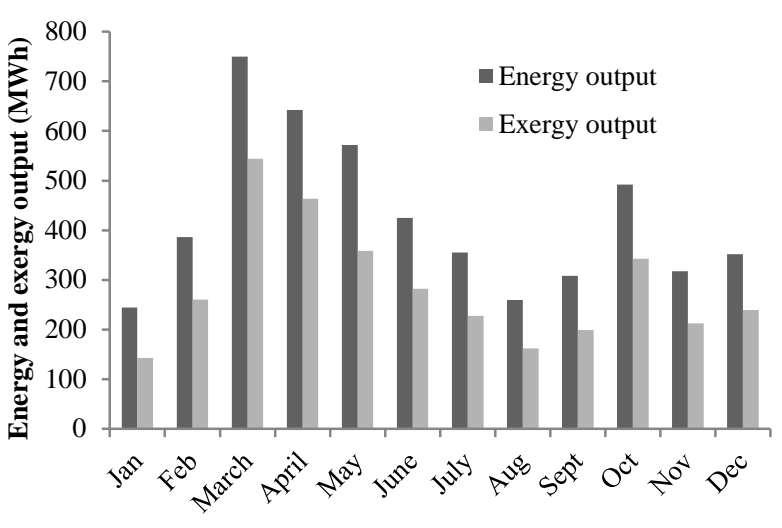

Fig. 4 Monthly energy and exergy output of DEORC

Fig. 3 and Fig. 4 show the monthly energy and exergy output of EORC and DEORC. It is observed that due to higher DNI in the month of March, April, May and October the energy and exergy output is higher while in the remaining months the energy and exergy output obtained is lower due to low value of DNI. The highest energy output (715.53 MWh) and exergy output (593.8 MWh) obtained in the month of March while lowest energy output (214.74 MWh) and exergy output (176.57 MWh) in the month of January in EORC. The maximum energy output in the month of March is $749.95 \mathrm{MWh}$ and maximum exergy output 544.38 MWh while least energy output 244.07 MWh and exergy output is $142.82 \mathrm{MWh}$ registered in the month of January in DEORC. The annual average energy output of EORC and DEORC is $4710.57 \mathrm{MWh}$ and 5104.97 MWh respectively while annual average exergy output of EORC and DEORC is $3893.86 \mathrm{MWh}$ and 3436.27 MWh respectively. It is concluded from Fig. 3 and Fig. 4 that yearly average energy output increases while average exergy output decreases with the addition of ejector refrigeration system in the EORC.

Fig. 5 shows the energy input/output and exergy input/output in EORC and DEORC at input thermodynamic parameters as shown in Table I. In EORC the total useful energy output of the cycle $\left(\dot{\mathrm{W}}_{\text {net }}+\dot{\mathrm{Q}}_{\mathrm{e}_{1}}\right)$ is $686 \mathrm{~kW}$ and the exergy output $\left(\dot{\mathrm{W}}_{\text {net }}+\dot{\mathrm{E}}_{\mathrm{e}_{1}}\right)$ is $571.22 \mathrm{~kW}$ is observed. In DEORC the total energy output $\left(\dot{\mathrm{W}}_{\text {net }}+\dot{\mathrm{Q}}_{\mathrm{e}_{1}}+\dot{\mathrm{Q}}_{\mathrm{e}_{2}}\right)$ is 711.2 $\mathrm{kW}$ and the exergy output $\left(\dot{\mathrm{W}}_{\text {net }}+\dot{\mathrm{E}}_{\mathrm{e}_{1}}+\dot{\mathrm{E}}_{\mathrm{e}_{2}}\right)$ is 535.26 is observed. It is clear that energy output in DEORC is higher than EORC.

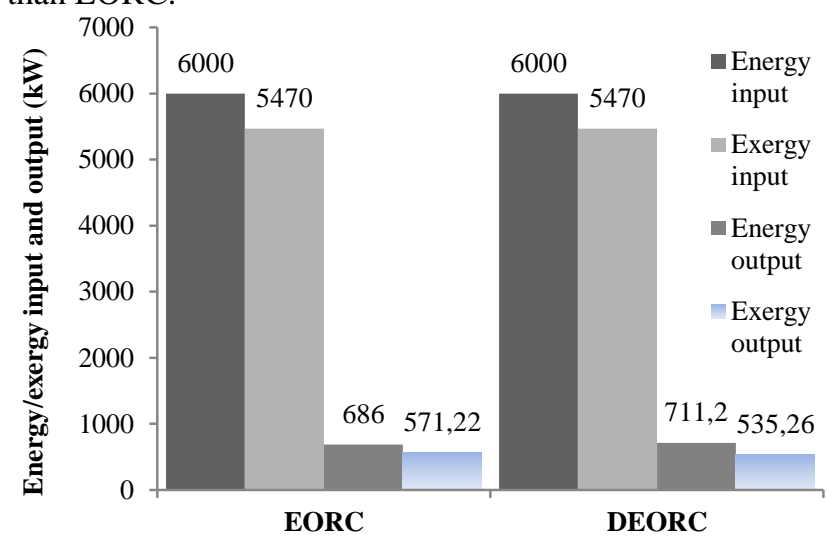

Fig. 5. Energy input/output, Exergy input/output of EORC and DEORC

Fig. 6, 7, and 8 shows the effect of turbine inlet temperature (TIT) on first law efficiency, second law 
efficiency and cooling/power ratio at different extraction ratio in EORC and DEORC. As the turbine inlet temperature increases the net power output increases due to increase in enthalpy drop in the turbine and cooling output increases due to increase in the enthalpy of R $141 \mathrm{~b}$ at the inlet of the ejector. This causes the increase in velocity of stream at the exit of the nozzle ejector, results in increase in entrainment ratio hence cooling output in EORC and DEORC increases. The rate of increase of net power output is higher than rate of increase of cooling output, the cooling to power ratio decreases. Due to increase in power output and cooling output the first law efficiency increases with increase in turbine inlet temperature. The second law efficiency increases with increase in turbine inlet temperature due to increase in total exergy output. The result shows that the first law efficiency of DEORC is greater than first law efficiency of EORC. With the increase in extraction ratio at the same turbine inlet temperature, the net power output decreases and cooling output increases. Since the rate of increase in cooling output is higher than the rate of decrease in net power output. The cooling to power ratio and first law efficiency increases while second law efficiency decreases as the extraction ratio increases. Fig. 6, 7, and 8 indicate that first law efficiency and cooling to power ratio is higher and second law of efficiency is lower for DEORC than EORC at the same working conditions.

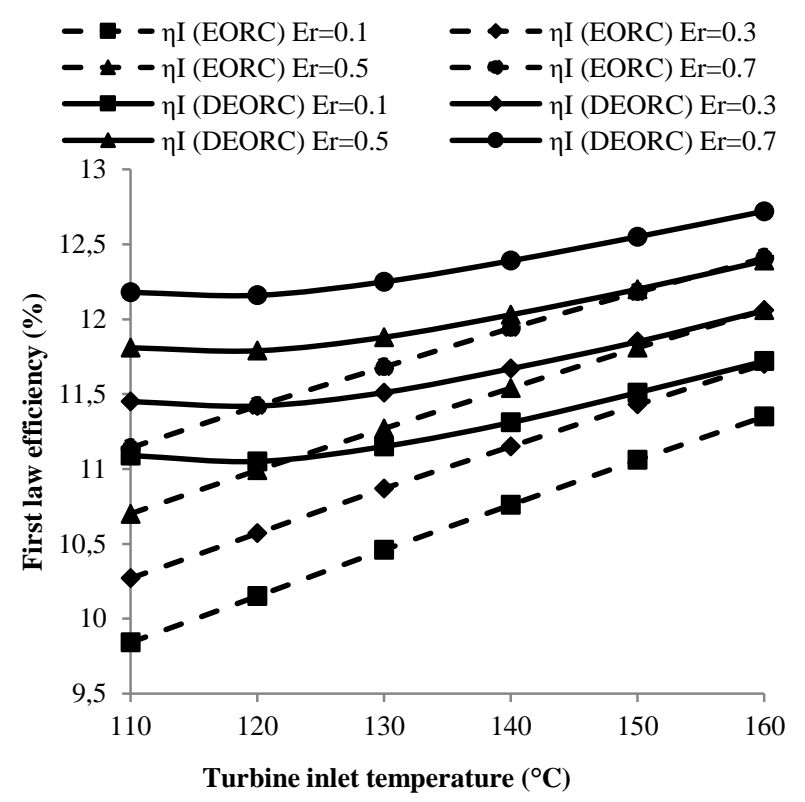

Fig. 6. Variation of first law efficiency with TIT at different extraction ratio

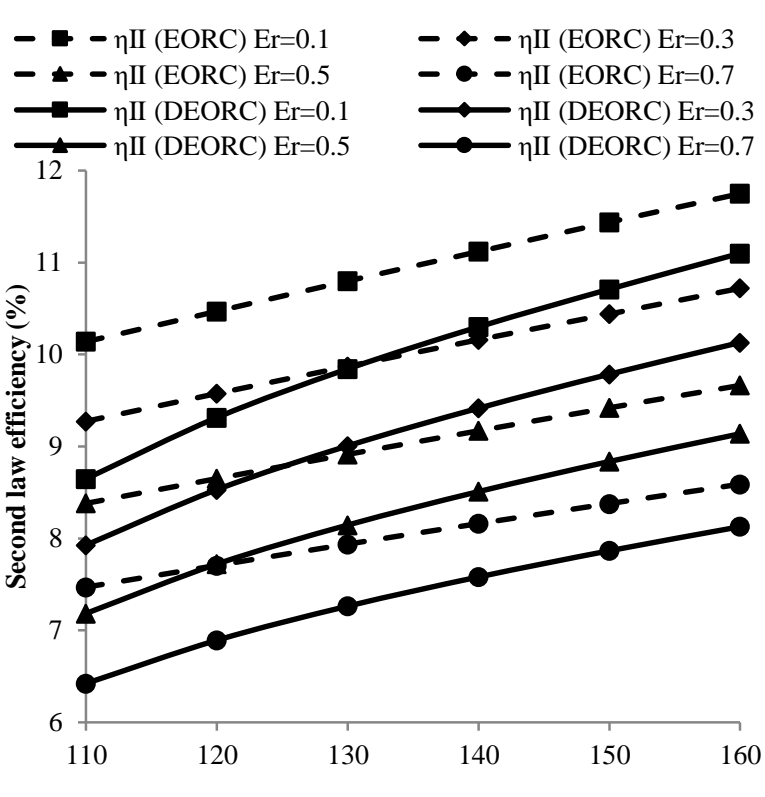

Turbine inlet temperature $\left({ }^{\circ} \mathrm{C}\right)$

Fig. 7. Variation of second law efficiency with TIT at different extraction ratio

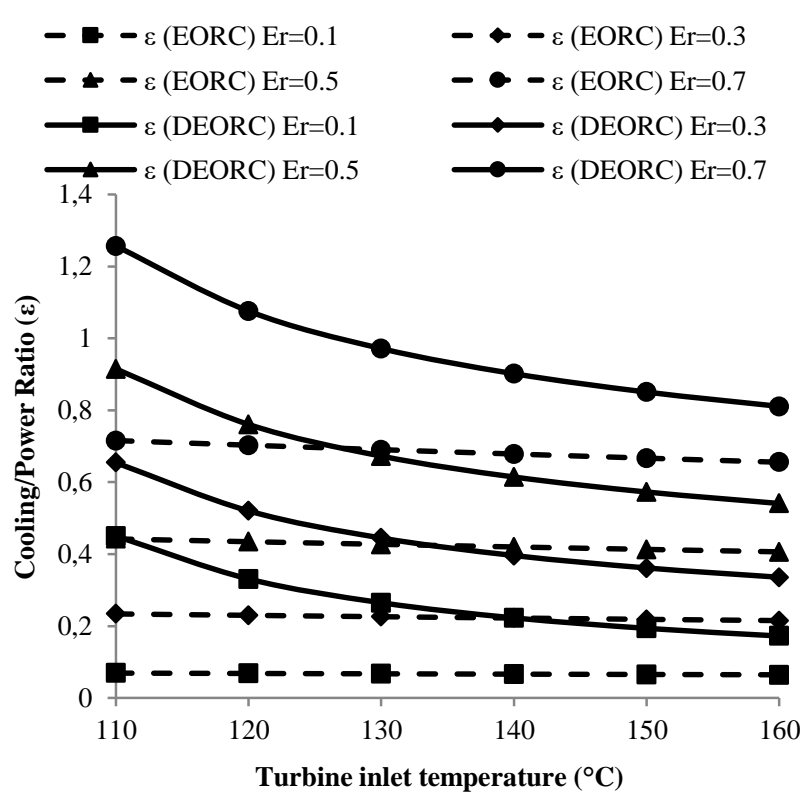

Fig. 8. Variation of Cooling/Power ratio with TIT at different extraction ratio 


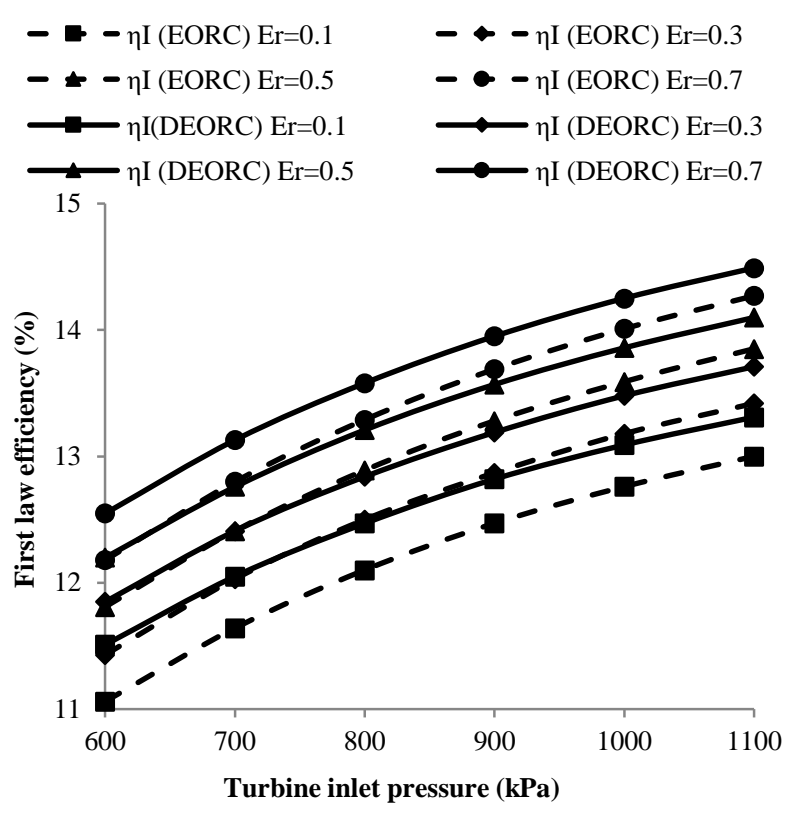

Fig. 9. Variation of First law efficiency with TIP at different extration ratio

Fig. 9, 10, and 11 show the effect of variation of turbine inlet pressure (TIP) on first law efficiency, second law efficiency and cooling to power ratio at different extraction ratio. As the turbine inlet pressure increases, the net power output increases and cooling output decreases for EORC and DEORC. The rate of increase in net power output is greater than rate of decrease in cooling output results in increase in first law efficiency and decrease in cooling to power ratio for EORC and DEORC with increase in turbine inlet pressure. The same trend for exergy efficiency observed with increase in turbine inlet pressure as shown in Fig. 10. With the increase in extraction ratio at the same turbine inlet pressure, the net power output decreases and cooling output increases. Since the rate of increase in cooling output is higher than the rate of decrease in net power output. The cooling to power ratio and first law efficiency increases while second law efficiency decreases as the extraction ratio increases. Fig. 9, 10, and 11 indicate that first law efficiency and cooling to power ratio is higher and second law efficiency is lower for DEORC than EORC at the same working conditions.

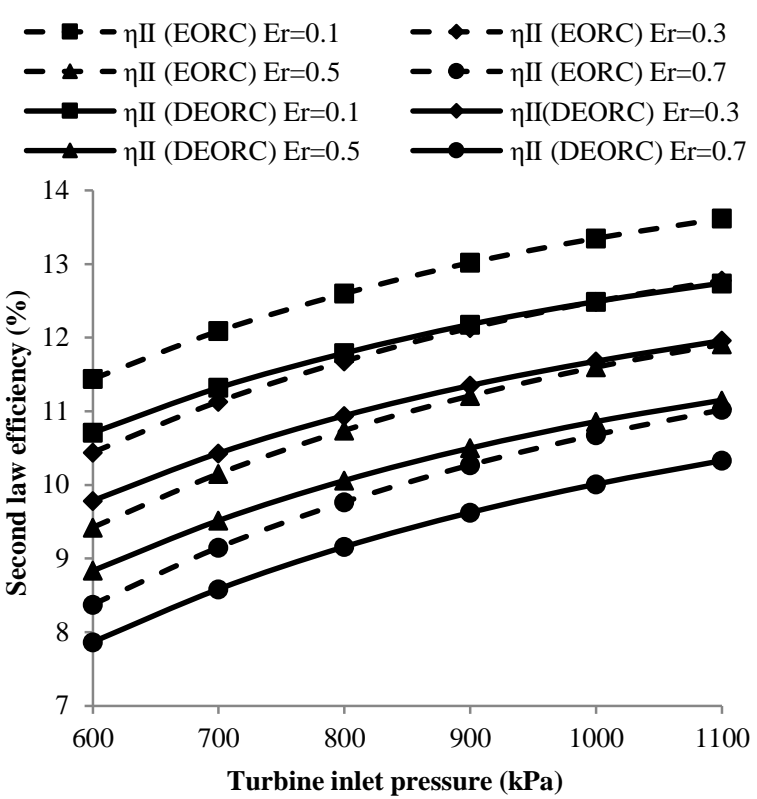

Fig. 10. Variation of Second law efficiency with TIP at different extration ratio

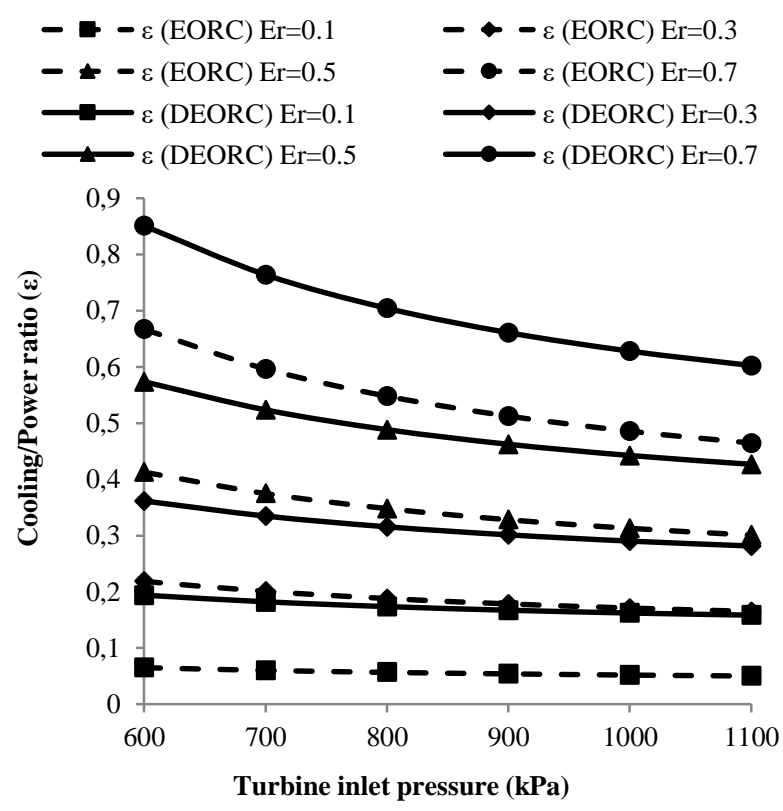

Fig. 11. Variation of Cooling/Power ratio with TIP at different extration ratio

Table II shows the performance of the EORC and DEORC. It is observed that the cooling and power output in DEORC is $711.23 \mathrm{~kW}$ as compared to $686 \mathrm{~kW}$ of EORC. The total energy output in DEORC is $11.85 \%$ of solar energy input $(100 \%)$ is observed.

TABle II: The Performance Of The Eorc And DeorC.

\begin{tabular}{|l|r|r|r|r|}
\hline & \multicolumn{2}{|l|}{$\begin{array}{l}\text { Organic Rankine cycle } \\
\text { with single ejector } \\
\text { (EORC) }\end{array}$} & \multicolumn{2}{l|}{$\begin{array}{l}\text { Organic Rankine cycle } \\
\text { with double ejector } \\
\text { (DEORC) }\end{array}$} \\
\cline { 2 - 5 } & Amount & $\begin{array}{l}\text { \% of solar } \\
\text { energy } \\
\text { input }\end{array}$ & Amount & $\begin{array}{l}\text { \% of solar } \\
\text { energy input }\end{array}$ \\
\hline $\begin{array}{l}\text { Solar energy } \\
\text { input (kW) }\end{array}$ & 6000.00 & 100.00 & 6000.00 & 100.00 \\
$\begin{array}{l}\text { Turbine work } \\
\text { (kW) }\end{array}$ & 572.50 & 9.54 & 531.90 & 8.85 \\
$\begin{array}{l}\text { Total pump } \\
\text { work (kW) }\end{array}$ & 9.55 & 0.159 & 9.37 & 0.15 \\
$\begin{array}{l}\text { Total cooling } \\
\text { output (kW) }\end{array}$ & 123.10 & 2.05 & 188.70 & 3.15 \\
\hline
\end{tabular}




\begin{tabular}{lrrrr}
$\begin{array}{l}\text { Net power } \\
\text { output }(\mathrm{kW})\end{array}$ & 562.90 & 9.38 & 522.53 & 8.70 \\
$\begin{array}{l}\text { Energy output } \\
(\mathrm{kW})\end{array}$ & 686.00 & 11.43 & 711.23 & 11.85 \\
$\begin{array}{l}\text { Energy loss } \\
(\mathrm{kW})\end{array}$ & 5314.00 & 88.57 & 5288.77 & 88.15 \\
\hline
\end{tabular}

Table III shows the distribution of exergy in EORC and DEORC. The total exergy output in DEORC is $535.26 \mathrm{~kW}$ as compared to exergy output of $571.22 \mathrm{~kW}$ in EORC.

\begin{tabular}{|c|c|c|c|c|}
\hline & \multicolumn{2}{|c|}{ EORC } & \multicolumn{2}{|c|}{ DEORC } \\
\hline & Amount & $\begin{array}{c}\% \text { of } \\
\text { exergy }\end{array}$ & Amount & $\begin{array}{c}\% \text { of } \\
\text { exergy }\end{array}$ \\
\hline Exergy input (kW) & 5470.00 & 100.00 & 5470.00 & 100.00 \\
\hline Exergy output (kW) & 571.22 & 10.44 & 535.26 & 9.785 \\
\hline $\begin{array}{l}\text { Exergy destruction/ } \\
\text { losses }(\mathrm{kW}) \text { : }\end{array}$ & & & & \\
\hline (i) Generator & 218.50 & 3.99 & 212.84 & 3.89 \\
\hline (ii) Turbine & 81.46 & 1.49 & 75.68 & 1.38 \\
\hline (111) Ejector & 87.23 & 1.59 & 110.19 & 2.02 \\
\hline (1v) Condenser & 60.44 & 1.10 & 63.75 & 1.165 \\
\hline (v) Pump & 9.36 & 0.17 & 9.19 & 0.168 \\
\hline (vi) Heat exchanger & 10.77 & 0.20 & 10.00 & 0.183 \\
\hline (vii) Throttle valve & 1.65 & 0.03 & 2.24 & 0.041 \\
\hline (viii) Evaporator & 4.85 & 0.09 & 5.92 & 0.108 \\
\hline $\begin{array}{l}\text { (ix) Parabolic trough } \\
\text { collector }\end{array}$ & 4424.52 & 80.90 & 4444.93 & 81.26 \\
\hline $\begin{array}{l}\text { Total Exergy } \\
\text { destruction/loss }(\mathrm{kW})\end{array}$ & 4898.78 & 89.56 & 4934.74 & 90.215 \\
\hline
\end{tabular}

\section{CONCLUSION}

This paper presents thermodynamic analysis of PTC based EORC \& DEORC using R141b as working fluid and Therminol VP1 as heat transfer fluid. The following main conclusions in this study are as follows:

- With the increase in inlet temperature of turbine $\left(110^{\circ} \mathrm{C}-160^{\circ} \mathrm{C}\right)$, the first and second law efficiency of EORC and DEORC increases while cooling /power ratio decreases.

- With the increase in the inlet pressure of turbine (600 $\mathrm{kPa}-1100 \mathrm{kPa}$ ), the first and second law efficiency of EORC and DEORC increases whereas cooling /power ratio decreases.

- The first law efficiency and cooling to power ratio is higher in DEORC as compared to EORC at the same working condition.

- $\quad$ In EORC the maximum energy output (715.53 MWh) and the maximum exergy output (593.8 MWh) obtained in the month of March while minimum energy output (214.74 MWh) and minimum exergy output (176.57 MWh) in the month of January. The annual average energy output of EORC is 4710.57 MWh while annual average exergy output of EORC 3436.27 MWh.

- $\quad$ In DEORC the highest energy output (749.95 MWh) and exergy output (544.38 MWh) is registered in the month of March while least energy output (244.07 MWh) and exergy output (142.82 MWh) registered in the month of January respectively. The annual average energy output of DEORC is 5104.97 MWh while annual average exergy output of DEORC is 3436.27 MWh respectively.

- With the addition of ejector in EORC the first law efficiency increases from $11.43 \%$ to $11.85 \%$ while second law efficiency decreases from $10.44 \%$ to
$9.785 \%$ at input thermodynamic parameters as shown in Table I.

\section{APPENDIX}

\section{Nomenclature}

$\mathrm{A}_{\mathrm{p}}$

I

$\dot{\mathrm{E}}$

Q

$\mathrm{T}$

$\mathrm{P}$

$\dot{\mathrm{W}}$

$\mathrm{h}$

$\dot{m}$

$\mathrm{s}$

G

EJ

C

HE

TV

E

Er

HTF

EORC

DEORC

PTC

Greek symbols

$\mu$

$\varepsilon$

$\eta$

Subscript

$\mathbf{e}_{1}$

$\mathbf{e}_{2}$

$\mathrm{P}$

$\mathrm{T}$

$1,2,3$.
Aperture area $\left(\mathrm{m}^{2}\right)$

Direct normal irradiance $\left(\mathrm{kWm}^{-2}\right)$

Exergy rate $(\mathrm{kW})$

Heat transfer rate $(\mathrm{kW})$

Absolute temperature (K), Turbine

Pressure (MPa), Pump

Power output/input (kW)

Specific enthalpy $\left(\mathrm{kJ} \mathrm{kg}^{-1}\right)$

Mass flow rate $\left(\mathrm{kg} \mathrm{s}^{-1}\right)$

Specific entropy $\left(\mathrm{kJ} \mathrm{kg}^{-1} \mathrm{~K}^{-1}\right)$

Heat recovery vapor generator (HRVG)

Ejector

Condenser

Heat exchanger

Throttle valve

Evaporator

Extraction ratio

Heat transfer fluid (Therminol VP1)

Organic Rankine cycle with single ejector

Organic Rankine cycle with double ejector

Parabolic trough collector

Entrainment ratio

Cooling to power ratio

Efficiency (\%)

Evaporator 1

Evaporator 2

Pump

Turbine

\section{REFERENCES}

[1] M. T. Dunham, and B. D. Iverson, "High-efficiency thermodynamic power cycles for concentrated solar power systems," Renewable and Sustainable Energy Reviews, Vol. 30, pp. 758-770, 2014.

[2] S. K. Tyagi, S. Wang, M. K. Singhal, S. C. Kaushik, and S.R. Park, "Exergy analysis and parametric study of concentrating type solar collectors," International Journal of Thermal Sciences, Vol. 46, pp. 1304-1310, 2007.

[3] R. V. Padilla, A. Fontalvo, G. Demirkaya, A. Mrtinez, and A. G. Quiroga, "Exergy analysis of parabolic trough solar receiver," Applied Thermal Engineering, Vol. 67, pp. 579-586, 2014.

[4] U. Herrmann, B. Kelly, and H. Price, "Two tank molten salt storage for parabolic trough solar power plants," Energy, Vol. 29, pp. 883 893, 2004.

[5] N. B. Desai, S. Bandyopadhyay J. K. Nayak, R. Banerjee, and S. B Kedare, "Simulation of 1MWe Solar Thermal Power Plant," ISES Solar World Congress, 2013.

[6] C. Tzivanidis, E. Bellos, and K. A. Antonopoulos, "Energetic and financial investigation of a stand-alone solar-thermal organic Rankine cycle power plant," Energy Conversion and Management, Vol. 126, pp. 421-433, 2016

[7] G. K. Alexis, "Performance parameters for the design of a combined refrigeration and electrical power cogeneration system," International Journal of Refrigeration, Vol. 30, pp. 1097-1103, 2007.

[8] B. Zheng, and Y. W. Weng, "A combined power and ejector refrigeration cycle for low temperature heat sources," Solar Energy, Vol. 84, pp. 784-791, 2010.

[9] M. M. Rashidi, O. A. Beg, and A. Aghagoli, "Utilization of waste heat in combined power and ejector refrigeration for a solar energy source," International Journal of Appl. Math and Mech., Vol. 8(17), pp. 1-16, 2012. 
[10] A. Habibzadeh, M. M. Rashidi, and N. Galanis, "Analysis of a combined power and ejector-refrigeration cycle using low temperature heat," Energy Conversion and Management, Vol. 65, pp. 381-391, 2013.

[11] X. Chen, Y. Su, S. Omer, and S. Riffat, "Theoretical investigations on combined power and ejector cooling system powered by low-grade energy source," International Journal of Low-Carbon Technologies Advance Access, Vol. 0, pp. 01-10, 2015.

[12] J. Wang, Y. Dai, and L. Gao, "Parametric analysis and optimization for a combined power and refrigeration cycle," Applied Energy, Vol.85, pp. 1071-1085, 2008

[13] Y. Dai, J. Wang, and L. Gao, "Exergy analysis, parametric analysis and optimization for a novel combined power and ejector refrigeration cycle," Applied Thermal Engineering, Vol. 29, pp. 1983-1990, 2009.

[14] D. K. Gupta, R. Kumar, and N. Kumar, "First and second law analysis of solar operated combined Rankine and ejector refrigeration cycle," Applied Solar Energy, Vol. 50(2), pp. 113-121, 2014.

[15] B. K. Agrawal, and M. N. Karimi, "Parametric, exergy and energy analysis of low grade energy and ejector refrigeration cycle," International Journal of Sustainable Building Technology and Urban Development, Vol. 4(2), pp. 170-176, 2013.

[16] NIST Standard Reference Database 23, 1998, NIST Thermodynamic and Transport Properties of Refrigerants and Refrigerants Mixtures REFPROP, Version 6.01.

[17] R. Petela, "Exergy of undiluted thermal radiation", Solar Energy, Vol.74 (6), pp. 469-488, 2003.

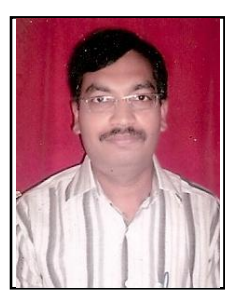

Devendra Kumar Gupta did his BE in Mechanical Engineering in 1991 and post-graduation, i.e. ME in Materials Handling in 2005 from Madhav Institute of Technology \& Science, Gwalior, M.P., India. Besides his industrial experience of four years, he has teaching experience of 16 years in the field of Thermal Engineering. Presently, he is pursuing his $\mathrm{PhD}$ from Department of Mechanical Engineering, Delhi Technological University (Government of NCT of Delhi), Bawana Road, Delhi.

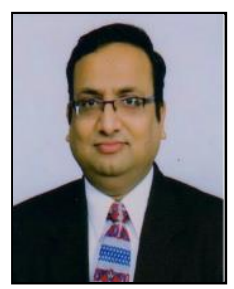

Dr. Rajesh Kumar did his B. Tech. in Mechanical Engineering from HBTI Kanpur in the year 1998 and ME in Thermal Engineering in the year 2000 from IIT, Roorkee. He did his $\mathrm{PhD}$ in the year 2008 from Jamia Millia Islamia, Delhi. He has teaching experience of more than 16 years in the field of Thermodynamics and refrigeration. Presently, he is working as an Associate Professor in the Department of Mechanical Engineering, Delhi Technological University (Government of NCT of Delhi), Bawana Road, Delhi. His several papers have been published in international journals having high impact factor. He is guiding $4 \mathrm{PhD}$ scholar in Mechanical Engineering department and supervised $12 \mathrm{M}$. Tech. dissertations in the area of thermal engineering.

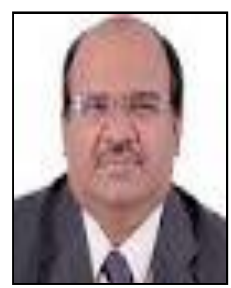

Dr. Naveen Kumar has more than 25 years of experience of industry, teaching and research, which includes more than 20 years at Delhi Technologica University (Formerly Delhi College of Engineering), where he is currently a Professor of Mechanical Engineering. Besides teaching at UG and PG levels, Prof. Naveen Kumar has made a significant contribution to R\&D in the area of alternative fuels for their utilization in Internal Combustion Engines. Apart from supervising Ph.D. and PG scholars, he has undertaken a number of major R\&D Projects sponsored by the Government and Industrial Houses. He has traveled extensively to abroad for delivering invited lectures and carrying out collaborative research. His work on biofuels is well recognized in India and abroad. 